\title{
Nuclear expression of claudin-3 in human colorectal adenocarcinoma cell lines and tissues
}

\author{
YASUNORI TOKUHARA $^{1,2}$, TATSUYA MORINISHI ${ }^{1}$, TORU MATSUNAGA $^{3}$, \\ MANABU SAKAI $^{4}$, TAKAYOSHI SAKAI ${ }^{5}$, HIROYUKI OHSAKI ${ }^{6}$, KYUICHI KADOTA ${ }^{3}$, \\ YOSHIO KUSHIDA ${ }^{3}$, REIJI HABA ${ }^{3}$ and EIICHIRO HIRAKAWA ${ }^{1}$
}

\begin{abstract}
${ }^{1}$ Laboratory of Pathology, Department of Medical Technology, Kagawa Prefectural University of Health Sciences, Takamatsu, Kagawa 761-0123; ${ }^{2}$ Department of Medical Technology, Ehime Prefectural University of Health Sciences, Tobe, Ehime 791-2101; ${ }^{3}$ Department of Diagnostic Pathology, University Hospital, Faculty of Medicine, Kagawa University, Miki, Kagawa 761-0793; ${ }^{4}$ Department of Clinical Laboratory, Osaka University Dental Hospital; ${ }^{5}$ Department of Oral-Facial Disorders, Osaka University Graduate School of Dentistry, Osaka 565-0871; ${ }^{6}$ Laboratory of Pathology, Department of Medical Biophysics, Kobe University Graduate School of Health Sciences, Kobe, Hyogo 654-0142, Japan
\end{abstract}

Received February 26, 2016; Accepted August 10, 2017

DOI: $10.3892 / \mathrm{ol} .2017 .7281$

\begin{abstract}
Claudins are members of a large family of transmembrane proteins, which are essential for the formation of tight junctions and have a significant effect on the biological behavior of tumor progression. Previous studies have demonstrated that several claudins show aberrant expression patterns in numerous types of cancer. The present study investigated the expression and localization of claudin-3 and claudin-7 in human colorectal adenocarcinoma cell lines and tissues. The protein expression levels of claudin-3 and claudin-7 were determined using immunocytochemical and immunohistochemical staining. Claudin-3, but not claudin-7, exhibited nuclear localization in the human colorectal adenocarcinoma Caco-2 and SW620 cell lines. Surgically resected colorectal adenocarcinoma tissue specimens were obtained, and the associations between the expression of claudin-3 or claudin-7 and various clinicopathological parameters were analyzed. The membranous expression rates of claudin-3 and claudin-7 were 58.0 and $50.0 \%$, while their nuclear expression rates were 22.0 and $2.0 \%$, respectively. The membranous expression of claudin-3 and claudin-7 was not associated with any clinicopathological factors, whereas the nuclear expression of claudin-3 was associated with histological type and was significantly increased in colorectal mucinous adenocarcinomas compared with that in well- to moderately-differentiated colorectal adenocarcinomas $(\mathrm{P}<0.01)$. However, no associations were observed between the
\end{abstract}

Correspondence to: Professor Eiichiro Hirakawa, Laboratory of Pathology, Department of Medical Technology, Kagawa Prefectural University of Health Sciences, 281-1 Hara, Mure-cho, Takamatsu, Kagawa 761-0123, Japan

E-mail: hirakawa@chs.pref.kagawa.jp

Key words: claudin-3, claudin-7, nuclear, membranous, colorectal adenocarcinoma, well- to moderately-differentiated, mucinous nuclear expression of claudin-7 and any clinicopathological parameter. In conclusion, the nuclear expression of claudin-3 in colorectal mucinous adenocarcinoma may be involved in the biological transformation of tumors. The results from the present study indicated that claudin-3 is an important protein associated with histological type and has potential as a prognostic marker. Although the mechanisms underlying the nuclear localization of claudin-3 in tumorigenesis have not yet been elucidated in detail, the present results indicated the potential of claudin-3 as a histopathological biomarker for colorectal adenocarcinomas.

\section{Introduction}

Colorectal cancer is one of the most prevalent types of malignant tumor and is a frequent cause of cancer-associated mortality worldwide $(1,2)$. The pathogenesis of colorectal cancer is known to occur through progression between adenomas and carcinomas (3). Loss of cell polarity and disruption of intracellular adhesion are frequently observed during this process and serve important functions in cancer progression $(4,5)$. The histological types of colorectal adenocarcinoma depend on the degree of glandular differentiation and cellular polarity (6). Tight junctions (TJs), which are the most apical type of cellular junction, maintain cell-cell adhesion, perform important roles in selective barriers and establish cellular polarity in epithelial cells (7-9). TJs have been associated with the regulation of cell proliferation and differentiation (10). TJs are typically lost in cancer, and this loss is involved in the invasive and metastatic phenotypes of tumor cells (11-14).

Membrane proteins, including claudin (15) and occludin (16), have been associated with TJs and are involved in the regulation of cell proliferation $(17,18)$. Claudin and occludin are tetraspanin proteins that extend their extracellular loops across adjacent cells (19). The C-terminal domain of claudins has a PDZ-binding motif that interacts with PDZ-domain proteins, including zona occludins (ZO)-1, -2 
and -3 (20). The claudin family is composed of 27 members that form homotypic and/or heterotypic interactions with each other $(21,22)$. Among the numerous TJ proteins, claudins are key functional proteins, and are expressed in various types of tissues and cells $(23,24)$. Additionally, claudins have been shown to have a significant effect on the biological behavior of tumor progression $(22,25)$.

Previous studies reported abnormal expression of several claudins. The expression of claudin-1 was observed to be upregulated in colorectal cancer $(19,26)$, melanoma (27) and nasopharyngeal carcinoma cells (28). The expression of claudin-2 was also upregulated in lung adenocarcinoma cells (29), whereas claudin-7 was demonstrated to be downregulated in invasive ductal carcinomas of the breast (30). The expression of claudins-1, -3 and -4 was previously reported to be upregulated in human colorectal cancer (31). Furthermore, several studies have reported that the translocation of claudins is associated with tumor cell proliferation and survival $(32,33)$. The expression of claudin-1 is upregulated in human colon cancers, particularly in the metastatic region, and is frequently mislocalized from the cell membrane to the cytoplasm and nucleus (19). The predominant cytoplasmic and nuclear localization of claudin-1 was revealed to exhibit anti-apoptotic activity in nasopharyngeal carcinoma cells (28). In addition, the nuclear distribution of claudin-2 has been shown to contribute to enhancing the proliferation of lung adenocarcinoma cells (34). However, the mechanisms underlying the different functions of claudins in tumorigenesis have not been clearly defined to date. Based on the aforementioned findings, it was hypothesized that the localization of claudins has specific significance in the process of cellular transformation in colorectal adenocarcinomas.

Therefore, the present study examined the cellular localization of claudins and determined whether claudins are associated with clinicopathological parameters of colorectal adenocarcinomas. Immunocytochemical and immunohistochemical staining were conducted using primary antibodies against claudin-3 and claudin-7. Cellular expression of claudin-3 and claudin-7 was investigated in the human colorectal adenocarcinoma cell lines Caco-2 and SW620. The clinicopathological associations (age, sex, histological type, lymphatic invasion, venous invasion, lymph node metastasis and depth of tumor invasion) with the expression of claudin-3 and claudin-7 were then examined in colorectal adenocarcinoma tissues.

\section{Materials and methods}

Cell culture. SW620 cells were obtained from Dainippon Sumimoto Pharma Co., Ltd. (Osaka, Japan), while Caco-2 cells were obtained from the American Type Culture Collection (Manassas, VA, USA). These cells were cultured in Dulbecco's modified Eagle's medium (Wako Pure Chemical Industries, Ltd., Osaka, Japan) supplemented with $10 \%$ heat-inactive fetal bovine serum (Biological Industries Israel Beit-Haemek, Kibbutz Beit-Haemek, Israel) and $1 \%$ penicillin-streptomycin at $37^{\circ} \mathrm{C}$ in a humidified atmosphere of $5 \% \mathrm{CO}_{2}$ /air.

RNA analysis. Total RNA was purified using an RNeasy Plus Mini kit (Qiagen China Co., Ltd., Shanghai, China). In the reverse transcription polymerase chain reaction (RT-PCR) analysis of claudin-3, claudin-7 and GAPDH expression, RT was performed with $1 \mu \mathrm{g}$ of RNA using a SuperScript VILO cDNA Synthesis kit (Invitrogen; Thermo Fisher Scientific, Inc., Waltham, MA, USA), and the reaction product was subsequently amplified by PCR using primers as follows: Claudin 3 forward, 5'-CAACACCATTATCCGGGACT-3' and reverse, 5'-CTTGGTGGCCGTGTACTTCT-3'; claudin 7 forward, 5'-AATTTTCATCGTGGCAGGTC-3' and reverse, 5'-AGG ACAGGAACAGGAGAGCA-3'; and GAPDH forward, 5'-CAA CGACCACTTTGTCAAGC-3' and reverse, 5'-TCTTCAAGG GGTCTACATGG-3'. The PCR reactions were conducted under the following conditions: $95^{\circ} \mathrm{C}$ for $10 \mathrm{~min}$ followed by 35 cycles of $95^{\circ} \mathrm{C}$ for $30 \mathrm{sec}, 63^{\circ} \mathrm{C}$ for $30 \mathrm{sec}, 71^{\circ} \mathrm{C}$ for $1 \mathrm{~min}$. The PCR products were separated on a $2 \%$ agarose gel and stained with ethidium bromide. Quantitative (q)PCR was performed with a Power SYBR-Green RNA-to-CT 1-Step kit (Applied Biosystems; Thermo Fisher Scientific, Inc.) using the Applied Biosystems StepOnePlus ${ }^{\text {TM }}$ Real-Time PCR system (Thermo Fisher Scientific, Inc.). The qPCR reactions were conducted under the following conditions: $48^{\circ} \mathrm{C}$ for $30 \mathrm{~min}, 95^{\circ} \mathrm{C}$ for $10 \mathrm{~min}$ followed by 40 cycles of $95^{\circ} \mathrm{C}$ for $15 \mathrm{sec}, 60^{\circ} \mathrm{C}$ for $1 \mathrm{~min}$ and melting curve at $95^{\circ} \mathrm{C}$ for $15 \mathrm{sec}, 60^{\circ} \mathrm{C}$ for $15 \mathrm{sec}$ and $95^{\circ} \mathrm{C}$ for $15 \mathrm{sec}$. The aforementioned primers were used, and the expression levels of the gene of interest were normalized to those of the endogenous control GAPDH messenger RNA (mRNA) (35). This protocol was repeated 3 times. The relative quantity of each gene was determined using the StepOnePlus Software (version 2.3; Applied Biosystems; Thermo Fisher Scientific, Inc.).

Protein extraction and western blotting. Caco-2 $\left(3 \times 10^{5}\right)$ and SW620 $\left(3 \times 10^{5}\right)$ cells were seeded on $40-\mathrm{mm}$ dishes and incubated at $37^{\circ} \mathrm{C}$ until confluent. Cells were washed with ice-cold PBS (Wako Pure Chemical Industries, Ltd.) twice, harvested with ice-cold lysis buffer (1\% Triton X-100, $150 \mathrm{mM} \mathrm{NaCl}$, $10 \mathrm{mM} \mathrm{MgCl}_{2}, 1 \mathrm{mM}$ EDTA and $50 \mathrm{mM}$ Tris-HCl, $\mathrm{pH}$ 7.5), and incubated on ice for $20 \mathrm{~min}$. The lysates were centrifuged at $20,600 \mathrm{x} \mathrm{g}$ for $20 \mathrm{~min}$ at $4^{\circ} \mathrm{C}$. The supernatants were collected and stored at $-80^{\circ} \mathrm{C}$ for subsequent analysis. Western blotting was performed subsequent to protein separation on a $15 \%$ polyacrylamide gel with $20 \mu \mathrm{l}$ of lysis buffer per lane. Protein samples separated by SDS-PAGE were transferred to a polyvinylidene fluoride (PVDF) membrane. The PVDF membrane was blocked at room temperature for $1 \mathrm{~h}$ in TBS-Tween-20 containing $2 \%$ skimmed milk powder, and then incubated with a primary antibody against rabbit polyclonal claudin-3 (cat. no. ab15102; 1:300; Abcam, Cambridge, UK), rabbit polyclonal claudin-7 (cat. no. ab27487; 1:1,000; Abcam) or rabbit monoclonal $\beta$-actin (cat. no. 4970S; 1:1,000; Cell Signaling Technology Inc., Danvers, MA, USA). Upon washing, the membranes were incubated with a horseradish peroxidase-conjugated anti-rabbit antibody (cat. no. 7074S; 1:5,000; Cell Signaling Technology, Inc., Osaka, Japan) at room temperature for $1 \mathrm{~h}$. Immunoreactivity was detected with an enhanced chemiluminescence kit Chemi-Lumi One L (Nacalai Tesque, Inc., Kyoto, Japan). Protein levels were quantified with ImageJ (version 1.51k) (36), and $\beta$-actin was used as the internal control.

Immunocytochemistry. Caco-2 cells were seeded on Nunc Lab-Tek chamber slides (Thermo Fisher Scientific, Inc.) and 
incubated at $37^{\circ} \mathrm{C}$ until confluent. Cells were subsequently washed twice with PBS and fixed with $3.7 \%$ formalin at room temperature for $15 \mathrm{~min}$. The cells were then permeabilized with $0.25 \%$ Triton X-100 in PBS for 10 min and blocked with $2 \%$ bovine serum albumin (Wako Pure Chemical Industries, Ltd.) in PBS for $1 \mathrm{~h}$. This was followed by incubations at room temperature for $2 \mathrm{~h}$ with anti-claudin-3 (1:100), anti-claudin-7 (1:100), mouse monoclonal anti- $\beta$-catenin (cat. no. M3539; 1:200; Dako; Agilent Technologies, Inc., Santa Clara, CA, USA) and mouse monoclonal anti-E-cadherin (cat. no. M3612; 1:200; Dako; Agilent Technologies, Inc.) antibodies. Cells were rinsed three times with PBS and incubated at room temperature for $15 \mathrm{~min}$ with secondary antibodies provided in the Histofine Simple Stain MAX PO (MULTI) detection reagent (universal immunoperoxidase polymer, anti-mouse and anti-rabbit; Nichirei Biosciences, Inc., Tokyo, Japan) according to the manufacturer's protocol. Cells were then stained with 3,3'-diaminobenzidine tetrahydrochloride (DAB) using the Histofine DAB substrate kit (Nichirei Biosciences, Inc., Tokyo, Japan) at room temperature for $1 \mathrm{~min}$. Sections were counterstained with Mayer's hematoxylin at room temperature for 4 min, dehydrated in a graded series of ethanol (Muto Pure Chemicals, Co., Ltd., Tokyo, Japan) from 80 to $100 \%$, cleared with $99 \%$ xylene (Muto Pure Chemicals, Co., Ltd.) for $15 \mathrm{~min}$ and mounted in malinol (Muto Pure Chemicals, Co., Ltd.). The expression of claudin-3 and claudin-7 in cells was observed at magnification, x200 using a light microscope (BX53; Olympus Corporation, Tokyo, Japan) and images were captured with a microscopic camera (DP20-5; Olympus Corporation).

Patients. Tissues were obtained from 100 patients with colorectal adenocarcinoma who underwent surgical resection between January 2010 and June 2014 at Kagawa University Hospital (Kagawa, Japan). The histological findings of these patients, in addition to their lymph node metastases, venous invasion and tumor node metastasis stages, were evaluated based on the Japanese Classification of Colorectal Carcinoma (8th edition) (37). All subjects provided written informed consent. The present study was conducted with the approval of the Institutional Research Ethics Committee of Kagawa Prefectural University of Health Sciences (Kagawa, Japan).

Immunohistochemistry. Tissues were obtained from primary tumors (4- $\mu \mathrm{m}$-thick), deparaffinized in $99 \%$ xylene for $15 \mathrm{~min}$, and then rehydrated in a graded series of ethanol, followed by antigen retrieval by microwave heating for $15 \mathrm{~min}$ at $2 \mathrm{~kW}$ in $0.01 \mathrm{M}$ citrate buffer ( $\mathrm{pH}$ 6.0). Endogenous peroxidase activity was blocked using $3 \%$ hydrogen peroxide (Wako Pure Chemical Industries, Ltd.) at room temperature for $10 \mathrm{~min}$, and non-specific binding was blocked with PBS containing $0.1 \%$ skimmed milk powder (Wako Pure Chemical Industries, Ltd.) at room temperature for $10 \mathrm{~min}$. Sections were incubated at room temperature for $2 \mathrm{~h}$ with the aforementioned anti-claudin-3 (1:200) and anti-claudin-7 (1:300) primary antibodies. Slides were rinsed three times with PBS and incubated at room temperature for $15 \mathrm{~min}$ with the secondary antibodies of Histofine Simple Stain MAX PO (MULTI), according to the manufacturer's protocol, and subsequently stained with DAB using the aforementioned DAB substrate kit (Nichirei Biosciences, Inc., Tokyo, Japan) at room temperature for $1 \mathrm{~min}$. Sections were counterstained with Mayer's hematoxylin at room temperature for $4 \mathrm{~min}$, dehydrated in a graded series of ethanol from 80 to $100 \%$, cleared with $99 \%$ xylene for $15 \mathrm{~min}$ and then mounted in malinol. Normal colorectal mucosa samples were used as positive controls. The expression of claudin-3 and claudin-7 in tissues was observed at x200 magnification using a light microscope (BX53; Olympus Corporation), and images were captured with a microscopic camera (DP20-5; Olympus Corporation).

Immunoscore. The classification of membranous claudin expression was based on the criteria of Jung et al (38). Briefly, immunostaining for claudin-3 or claudin-7 was assessed using the following scoring: No staining, $0 ;<25 \%$ cells positive and incomplete membranous staining, $1+; 25-50 \%$ cells positive and incomplete membranous staining, $2+; 50-75 \%$ cells positive and complete or incomplete membranous staining, 3+; and $>75 \%$ cells positive and complete membranous staining, $4+$. In the evaluation, the expression levels of claudin-3 and claudin- 7 were grouped into negative $(0$ and $1+)$ and positive $(2+, 3+$ and $4+)$ groups.

The classification of nuclear claudin expression was scored by a similar method of membranous staining: Negative expression, $0(0 \%)$ and $1+(<25 \%)$; positive expression, $2+(25-50 \%)$, $3+(50-75 \%)$ and $4+(>75 \%)$.

Statistical analysis. Data was expressed as the mean \pm standard deviation. Differences between two groups were evaluated with the paired Student's t-test. Univariate analysis was performed using the $\chi^{2}$ or Fisher's exact test for categorical data. All statistical analyses were performed using SPSS 23.0 software (IBM SPSS, Armonk, NY, USA). P<0.05 was considered to indicate a statistically significant difference.

\section{Results}

Claudin-3 and claudin-7 are expressed in human colorectal adenocarcinoma cell lines. In order to study the expression of claudin-3 and claudin-7 in human colorectal adenocarcinoma cell lines, RT-PCR was performed using specific primers. RT-PCR amplification yielded DNA fragments of the expected size ( $200 \mathrm{bp}$ ), indicating the presence of claudin-3 and claudin-7 in Caco-2 and SW620 cells (Fig. 1A). qPCR revealed that claudin-3 mRNA levels were significantly lower in Caco-2 cells compared with those in SW620 cells, while claudin-7 mRNA levels were significantly increased in Caco-2 cells compared with those in SW620 cells (Fig. 1B). Western blotting was performed using a primary antibody against claudin-3 or claudin-7 to determine claudin protein expression in Caco-2 and SW620 cells. The specific band corresponding to claudin-3 or claudin-7 was detected in Caco-2 and SW620 cells (Fig. 2A). Furthermore, the protein expression levels of claudin-3 were significantly lower in Caco-2 cells compared with those in SW620 cells, while the protein expression levels of claudin-7 were significantly increased in Caco- 2 cells compared with those in SW620 cells (Fig. 2B).

Localization of claudin-3 and claudin-7 in Caco-2 and SW620 cells. An immunocytochemical analysis was performed to determine the subcellular localization of claudin-3 and 

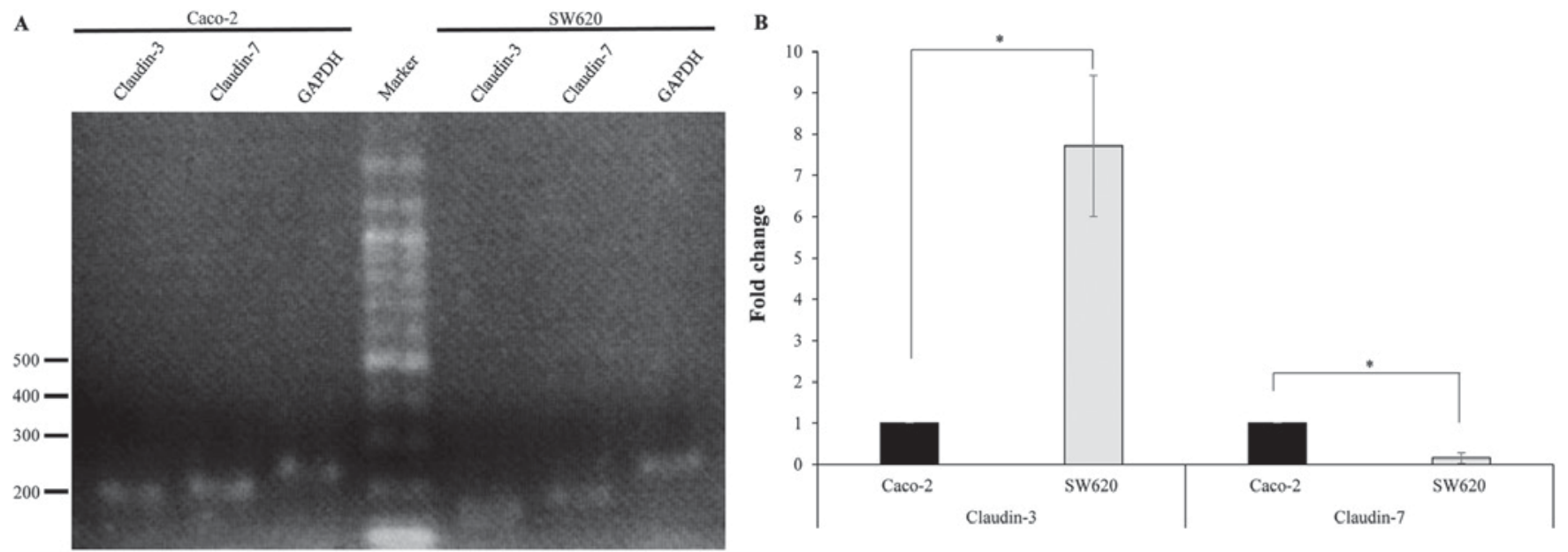

Figure 1. Claudin-3 and claudin-7 mRNA are expressed in Caco-2 and SW620 cells. (A) RT-qPCR analysis was performed using claudin-3, claudin-7 and GAPDH-specific primers. The size in bp of the DNA molecular marker is indicated. (B) qPCR analysis of the mRNA levels of claudin-3 and claudin-7. GAPDH mRNA was used as the endogenous control for the expression levels of the genes of interest. Data are presented as the mean \pm standard deviation $(n=3)$. $P<0.01$. RT-PCR, reverse transcription polymerase chain reaction; qPCR, quantitative PCR; mRNA, messenger RNA.

A

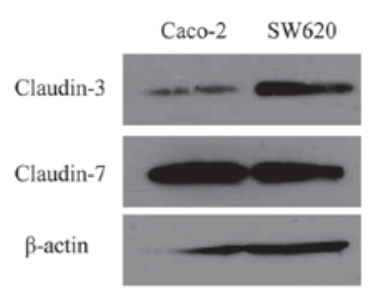

B

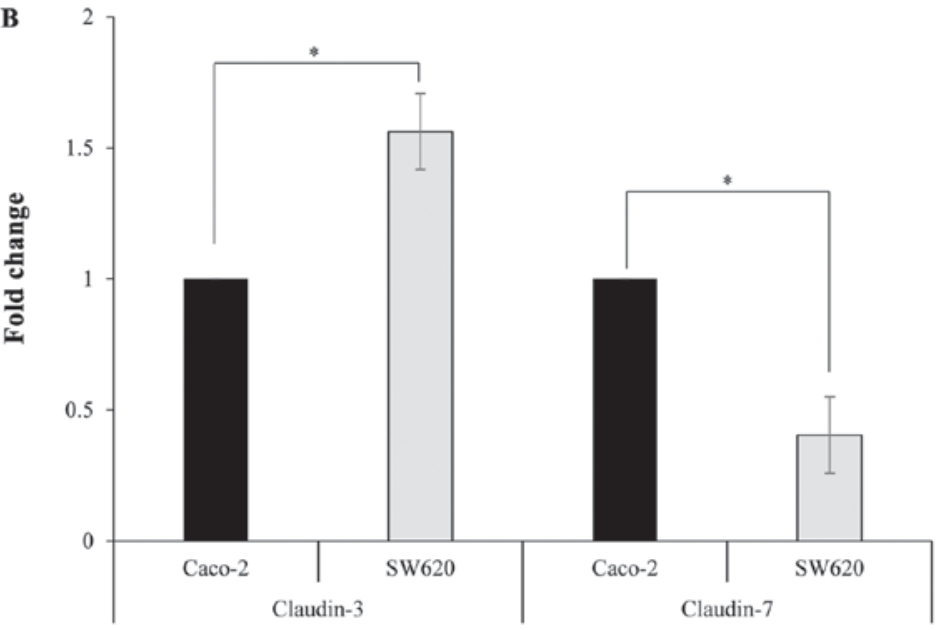

Figure 2. Claudin-3 and claudin-7 proteins are expressed in Caco-2 and SW620 cells. (A) Western blot analysis was performed with total protein extracted from Caco-2 and SW620 cells. (B) Protein levels were quantified and data are presented as the mean \pm standard deviation $(\mathrm{n}=3) .{ }^{*} \mathrm{P}<0.01$.

claudin-7 in Caco-2 and SW620 cells. Staining with antibodies against E-cadherin, $\beta$-catenin and claudin-7 revealed immunoreactivity predominantly at the site of cell-cell contact for claudin-7, whereas claudin-3 immunoreactivity was localized in the nucleus in Caco-2 cells (Fig. 3). Similar results were obtained for staining with an anti-claudin-3 antibody in SW620 cells (Fig. 3). However, claudin-7 and $\beta$-catenin were largely localized at the cytoplasm, and E-cadherin was lowly expressed in SW620 cells (Fig. 3).

Expression and localization of claudin-3 and claudin-7 proteins in colorectal adenocarcinoma tissues. The expression of claudin-3 and claudin-7 was investigated in colorectal adenocarcinoma tissues. The protein expression levels of claudin-3 and claudin-7 were determined using immunohistochemical staining. Table I summarizes the clinical parameters of patients with colorectal adenocarcinoma. A total of $59(59.0 \%)$ patients were men and $41(41.0 \%)$ were women, with a median age of 69 years (range, 39-95 years). An analysis of tumor samples revealed that $1(1.0 \%)$ patient had stage 0,15 $(15.0 \%)$ patients had stage I, $49(49.0 \%)$ patients had stage II, $34(34.0 \%)$ patients had stage III and $1(1.0 \%)$ patient had stage IV colorectal adenocarcinoma. Claudin-3 and claudin-7 were primarily expressed in the cell membrane of colorectal adenocarcinoma cells; certain samples exhibited nuclear claudin expression and a low level of cytoplasmic staining (Fig. 4). The membranous expression rates of claudin-3 and claudin-7 were 58.0 and $50.0 \%$, respectively (Table II). The nuclear expression rates of claudin-3 and claudin-7 were 22.0 and $2.0 \%$, respectively (Table II). Therefore, membranous and nuclear claudin expression in colorectal adenocarcinoma tissues was evaluated.

The membranous expression of claudin-3 or claudin-7 was not associated with any clinicopathological factors (Fig. 4 and Table III). As shown in Fig. 4 and Table IV, the nuclear expression of claudin-3 was associated with histological type and was significantly increased in colorectal mucinous adenocarcinomas compared with that in 
Table I. Clinical characteristics of 100 patients with colorectal adenocarcinoma.

\begin{tabular}{|c|c|}
\hline Characteristics & Patients, $\mathrm{n}$ \\
\hline Mean age \pm standard deviation, years & $68.5 \pm 11.4$ \\
\hline \multicolumn{2}{|l|}{ Sex } \\
\hline Male & 59 \\
\hline Female & 41 \\
\hline \multicolumn{2}{|l|}{ Histological type } \\
\hline Well- to moderately-differentiated & 81 \\
\hline Mucinous & 19 \\
\hline \multicolumn{2}{|l|}{ Lymphatic invasion } \\
\hline Negative & 31 \\
\hline Positive & 69 \\
\hline \multicolumn{2}{|l|}{ Venous invasion } \\
\hline Negative & 20 \\
\hline Positive & 80 \\
\hline \multicolumn{2}{|l|}{ Lymph node metastasis } \\
\hline N0 & 65 \\
\hline N1 & 28 \\
\hline $\mathrm{N} 2$ & 6 \\
\hline N3 & 1 \\
\hline \multicolumn{2}{|l|}{ Depth of tumor invasion } \\
\hline Tis & 1 \\
\hline $\mathrm{T} 1$ & 10 \\
\hline $\mathrm{T} 2$ & 6 \\
\hline T3 & 52 \\
\hline $\mathrm{T} 4$ & 31 \\
\hline \multicolumn{2}{|l|}{ Stage } \\
\hline 0 & 1 \\
\hline I & 15 \\
\hline II & 49 \\
\hline III & 34 \\
\hline IV & 1 \\
\hline
\end{tabular}

well- to moderately-differentiated colorectal adenocarcinomas $(\mathrm{P}<0.01)$. However, no associations were observed between the nuclear expression of claudin-3 and age, gender, lymphatic invasion, venous invasion, depth of tumor invasion, lymph node metastasis or stage of colorectal adenocarcinoma in the present cohort of patients (Table IV). The nuclear expression rate of claudin-7 in colorectal mucinous adenocarcinomas was similar to that in well- to moderately-differentiated colorectal adenocarcinomas; therefore, claudin-7 was not observed to be associated with any clinicopathological factor (Table IV).

\section{Discussion}

The present study examined the expression of claudin-3 and claudin-7 in human colorectal adenocarcinoma cell lines and in 100 patients with colorectal adenocarcinoma. The expression of claudin-3 was localized in the nuclei of Caco-2 and SW620 cells, and the nuclear expression of claudin-3 was significantly increased in colorectal mucinous adenocarcinomas compared
Table II. Immunohistochemical staining for positive expression rate (membrane or nucleus) ${ }^{\mathrm{a}}$ of claudins in 100 colorectal adenocarcinoma tissue samples.

\begin{tabular}{lcc}
\hline Claudin & $\begin{array}{c}\text { Membranous } \\
\text { expression, } \mathrm{n}(\%)\end{array}$ & $\begin{array}{c}\text { Nuclear } \\
\text { expression, } \mathrm{n}(\%)\end{array}$ \\
\hline Claudin-3 & $58(58.0)$ & $22(22.0)$ \\
Claudin-7 & $50(50.0)$ & $2(2.0)$ \\
\hline
\end{tabular}

${ }^{a}$ Data were grouped according to immunostaining scores based on positive and incomplete staining (\%): Negative expression, $0(0 \%)$ and $1+(<25 \%)$; and positive expression, $2+(25-50 \%), 3+(50-75 \%)$ and $4+(>75 \%)$.

with that in well- to moderately-differentiated colorectal adenocarcinomas. However, no associations were observed between the expression of claudin-7 in colorectal adenocarcinomas and clinicopathological parameters. Therefore, the present results provided evidence for the development of a useful marker for predicting cancer progression and prognosis in colorectal adenocarcinoma, since the nuclear expression of claudin-3 may be a phenotypic feature of colorectal mucinous adenocarcinomas.

An important result of the present study is the nuclear localization of claudin-3 in human colorectal adenocarcinoma cell lines (Caco-2 and SW620) and tissues (Figs. 3 and 4C). Although claudins are members of the tetraspanin family of proteins, which are integral to the structure and function of TJs, changes in the cellular localization of claudins serve an important role during tumorigenesis (19). Previous studies reported that the expression of claudin-1 increased in human colon cancers with mislocalization from the cell membrane to the nucleus and cytoplasm (19), the predominant cytoplasmic and nuclear localization of claudin-1 reduced apoptosis in nasopharyngeal carcinoma cells (28), and claudin-1 showed loss of membrane expression and increased nuclear localization in follicular thyroid carcinoma (39). The cytoplasmic expression of claudin-1 in metastatic melanoma cells was also shown to be critical for increased malignancy $(27,40)$. In addition, nuclear distribution of claudin-2 resulted in enhanced proliferation in human lung adenocarcinoma cells (34). As aforementioned, the cellular distribution of claudins has been reported in several types of cancer (41); however, the pathophysiological functions of nuclear claudins have not yet been determined. The present results indicated that claudin-3 is mainly distributed in the nucleus of Caco-2 and SW620 cells. Therefore, it was hypothesized that nuclear claudin-3, but not claudin-7, serves an important function in enhancing cell proliferation in human colorectal adenocarcinoma cell lines.

The nuclear localization of several cell junction proteins, including ZO-1, ZO-2 and $\beta$-catenin, is known to be associated with oncogenic transformation and cell proliferation $(42,43)$. In addition, ZO-1 and ZO-2 contain a nuclear localization signal (NLS), and exhibit shuttle localization between the cytoplasm and nucleus $(42,43)$. Therefore, the amino acid sequence of claudin-3 was analyzed using an NLS prediction program (cNLS Mapper; http://nls-mapper.iab.keio. ac.jp/cgi-bin/NLS_Mapper_form.cgi) (44), but no putative 

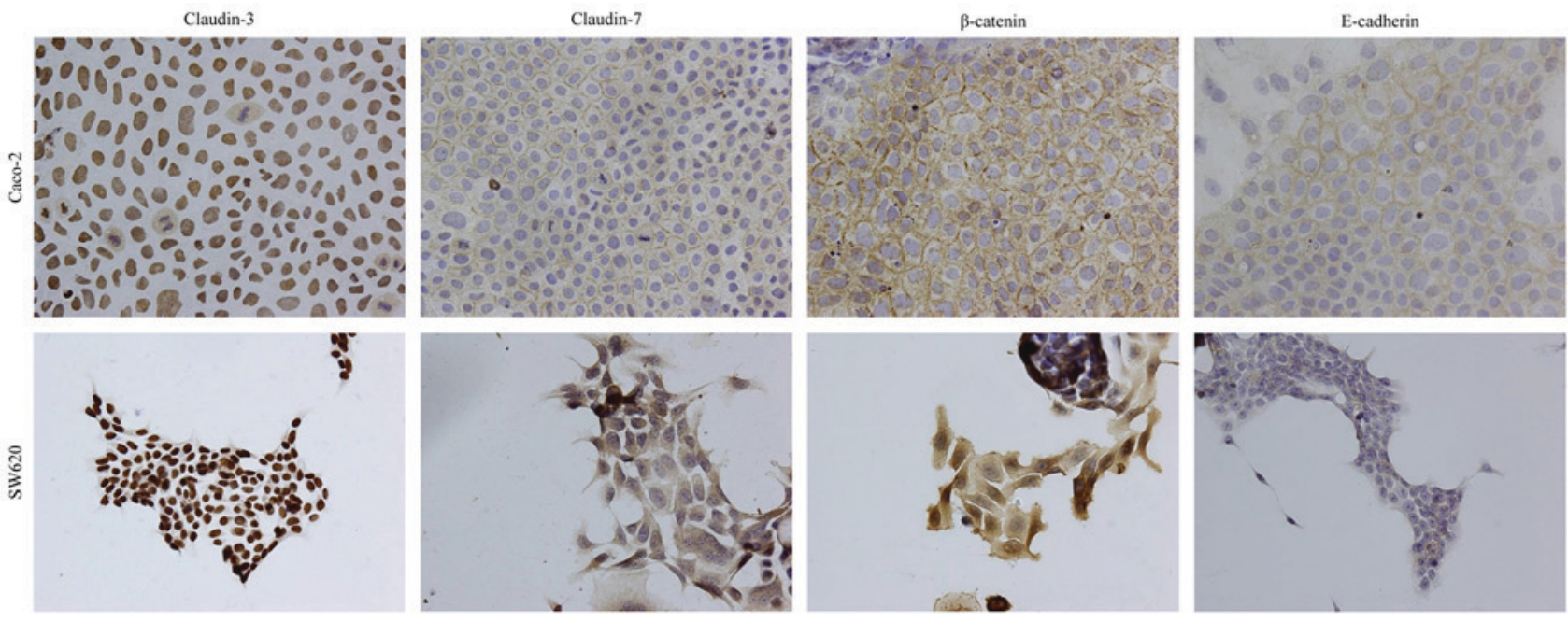

Figure 3. Cellular distribution of claudin-3, claudin-7, $\beta$-catenin and E-cadherin. Immunocytochemical analyses were performed in Caco-2 and SW620 cells (magnification, x200). The panels represent the immunoreactivity of claudin-3, claudin-7, $\beta$-catenin and E-cadherin in Caco-2 (top panels) and SW620 (bottom panels) cells.
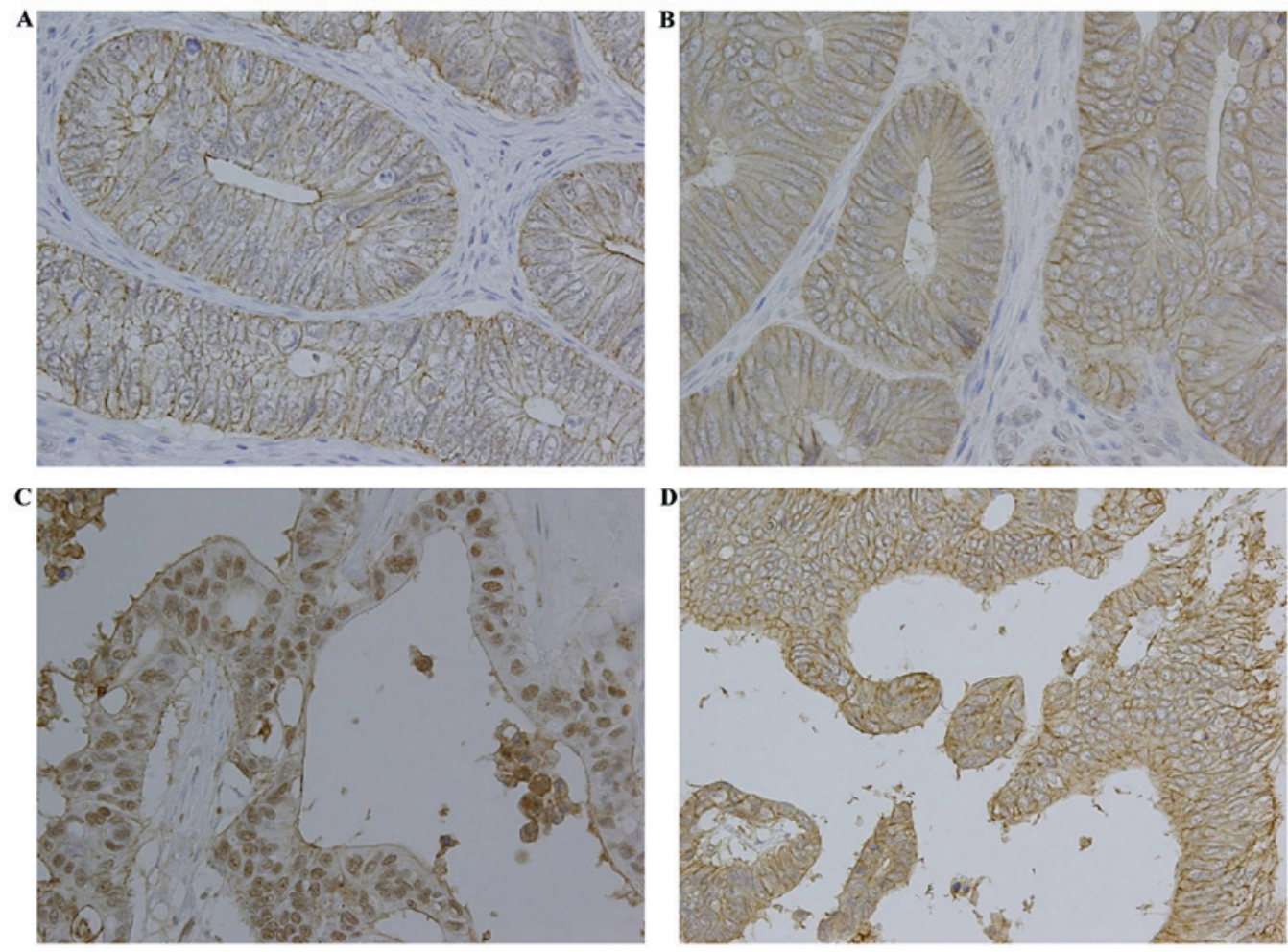

Figure 4. Immunohistochemical staining of claudin-3 and claudin-7 in colorectal adenocarcinoma (magnification, x200). Positive membranous expression of (A) claudin-3 and (B) claudin-7 in well- to moderately-differentiated colorectal adenocarcinoma. (C) Positive nuclear expression of claudin-3 in colorectal mucinous adenocarcinoma. (D) Positive membranous expression of claudin-7 in colorectal mucinous adenocarcinoma.

NLS was detected. Although NLS is a well-known sequence of nuclear import elements, other sequences, including the PDZ domain, are known to be important for nuclear localization (45). A previous study reported that the nuclear localization of armadillo-repeat gene deleted in velocardiofacial syndrome (ARVCF), an armadillo-repeat protein of the p120ctn family, may be mediated by the PDZ domain of ZO-2 (46). One of the potential mechanisms by which claudin-3 may translocate to the nucleus is through interaction with the PDZ domain of ZO-2 in a manner similar to that of ARVCF. Several studies have indicated that tumor suppressors, including adenomatous polyposis coli and breast cancer gene 1, translocate to the nucleus via an NLS-independent pathway (47). Additionally, $\beta$-catenin, which has no NLS, was imported into the nucleus by binding directly to the nuclear pore machinery, similarly to importin- $\beta / \beta$-karyopherin or other importin- $\beta$-like import factors (48). Another potential mechanism is that claudin-3 relocates from the cellular membrane to the nucleus using an NLS-independent import pathway similar to that used by these proteins. 
Table III. Association between membranous claudin expression and clinicopathological characteristics of colorectal adenocarcinoma in 100 tissue samples from patients.

\begin{tabular}{|c|c|c|c|c|c|c|}
\hline \multirow[b]{2}{*}{ Characteristics } & \multicolumn{3}{|c|}{ Claudin-3 expression, $\mathrm{n}$} & \multicolumn{3}{|c|}{ Claudin-7 expression, $\mathrm{n}$} \\
\hline & $(-)$ & $(+)$ & P-value & $(-)$ & $(+)$ & P-value \\
\hline Age, years & & & 0.389 & & & 1.000 \\
\hline$<60$ & 11 & 11 & & 11 & 11 & \\
\hline$\geq 60$ & 31 & 47 & & 39 & 39 & \\
\hline Sex & & & 0.185 & & & 0.542 \\
\hline Male & 28 & 31 & & 31 & 28 & \\
\hline Female & 14 & 27 & & 19 & 22 & \\
\hline Histological type & & & 0.432 & & & 0.308 \\
\hline Well- to moderately-differentiated & 32 & 49 & & 38 & 43 & \\
\hline Mucinous & 10 & 9 & & 12 & 7 & \\
\hline Lymphatic invasion & & & 0.386 & & & 0.130 \\
\hline Negative & 15 & 16 & & 12 & 19 & \\
\hline Positive & 27 & 42 & & 38 & 31 & \\
\hline Venous invasion & & & 0.648 & & & 0.453 \\
\hline Negative & 7 & 13 & & 8 & 12 & \\
\hline Positive & 35 & 45 & & 42 & 38 & \\
\hline Lymph node metastasis & & & 0.426 & & & 0.295 \\
\hline No & 25 & 40 & & 29 & 36 & \\
\hline N1 & 13 & 15 & & 17 & 11 & \\
\hline $\mathrm{N} 2$ & 4 & 2 & & 4 & 2 & \\
\hline N3 & 0 & 1 & & 0 & 1 & \\
\hline Depth of tumor invasion & & & 0.740 & & & 0.563 \\
\hline Tis & 0 & 1 & & 0 & 1 & \\
\hline $\mathrm{T} 1$ & 3 & 7 & & 3 & 7 & \\
\hline $\mathrm{T} 2$ & 3 & 3 & & 3 & 3 & \\
\hline $\mathrm{T} 3$ & 24 & 28 & & 27 & 25 & \\
\hline $\mathrm{T} 4$ & 12 & 19 & & 17 & 14 & \\
\hline Stage & & & 0.586 & & & 0.323 \\
\hline 0 & 0 & 1 & & 0 & 1 & \\
\hline I & 5 & 10 & & 6 & 9 & \\
\hline II & 20 & 29 & & 23 & 26 & \\
\hline III & 17 & 17 & & 21 & 13 & \\
\hline IV & 0 & 1 & & 0 & 1 & \\
\hline
\end{tabular}

The membranous localization of $\beta$-catenin is necessary for cadherin-mediated cell adhesion (49), and its cytoplasmic and nuclear localization have been associated with oncogenesis (50). Furthermore, $\beta$-catenin regulates the expression of claudin-1 in colorectal cancer cells (26) and that of claudin-3 in primary brain endothelial cells (51). Although the precise mechanism through which $\beta$-catenin regulates the expression of claudin-1 and claudin-3 has not yet been defined, Wnt signaling may be involved in the expression and localization of claudins. As presented in Fig. 3, $\beta$-catenin was largely localized at the cytoplasm, and E-cadherin was weakly expressed in SW620 cells, whereas $\beta$-catenin and E-cadherin were primarily localized at the cell membrane in Caco- 2 cells The expression patterns of these proteins in SW620 cells were consistent with those reported in previous studies (19).
Additionally, overexpression of claudin-3 in Caco-2 cells may induce changes in the localization of $\beta$-catenin, since overexpression of claudin-1 in the primary colon adenocarcinoma SW480 cell line was previously reported to induce changes in the localization of $\beta$-catenin from the cell membrane to the cytosol (19). The interactions between nuclear claudin-3 and $\beta$-catenin in colorectal adenocarcinoma cell proliferation and metastasis will be further investigated by our group.

The present study detected mRNA and protein expression of claudin-3 and claudin-7 in Caco-2 and SW620 cells, and revealed that the expression levels of claudin-3 were significantly increased in SW620 cells compared with those in Caco-2 cells, whereas the expression levels of claudin-7 were lower in SW620 cells compared with those in Caco-2 cells (Figs. 1 and 2). In addition, in SW620 cells, the 
Table IV. Association between nuclear claudin expression and clinicopathological characteristics of colorectal adenocarcinoma in 100 tissue samples from patients.

\begin{tabular}{|c|c|c|c|c|c|c|}
\hline \multirow[b]{2}{*}{ Characteristics } & \multicolumn{3}{|c|}{ Claudin-3 expression } & \multicolumn{3}{|c|}{ Claudin-7 expression } \\
\hline & $(-)$ & $(+)$ & P-value & $(-)$ & $(+)$ & P-value \\
\hline Age, years & & & 0.563 & & & 1.000 \\
\hline$<60$ & 16 & 6 & & 22 & 0 & \\
\hline$\geq 60$ & 62 & 16 & & 76 & 2 & \\
\hline Sex & & & 0.088 & & & 0.511 \\
\hline Male & 50 & 9 & & 57 & 2 & \\
\hline Female & 28 & 13 & & 41 & 0 & \\
\hline Histological type & & & 0.001 & & & 0.345 \\
\hline Well- to moderately-differentiated & 69 & 12 & & 80 & 1 & \\
\hline Mucinous & 9 & 10 & & 18 & 1 & \\
\hline Lymphatic invasion & & & 0.867 & & & 0.526 \\
\hline Negative & 25 & 6 & & 30 & 1 & \\
\hline Positive & 53 & 16 & & 68 & 1 & \\
\hline Venous invasion & & & 0.370 & & & 1.000 \\
\hline Negative & 14 & 6 & & 20 & 0 & \\
\hline Positive & 64 & 16 & & 78 & 2 & \\
\hline Lymph node metastasis & & & 0.794 & & & 0.777 \\
\hline No & 52 & 13 & & 63 & 2 & \\
\hline $\mathrm{N} 1$ & 21 & 7 & & 28 & 0 & \\
\hline $\mathrm{N} 2$ & 4 & 2 & & 6 & 0 & \\
\hline N3 & 1 & 0 & & 1 & 0 & \\
\hline Depth of tumor invasion & & & 0.181 & & & 0.319 \\
\hline Tis & 1 & 0 & & 1 & 0 & \\
\hline $\mathrm{T} 1$ & 8 & 2 & & 9 & 1 & \\
\hline $\mathrm{T} 2$ & 4 & 2 & & 6 & 0 & \\
\hline $\mathrm{T} 3$ & 45 & 7 & & 52 & 0 & \\
\hline $\mathrm{T} 4$ & 20 & 11 & & 30 & 1 & \\
\hline Stage & & & 0.350 & & & 0.662 \\
\hline 0 & 1 & 0 & & 1 & 0 & \\
\hline I & 11 & 4 & & 14 & 1 & \\
\hline II & 40 & 9 & & 48 & 1 & \\
\hline III & 26 & 8 & & 34 & 0 & \\
\hline IV & 0 & 1 & & 1 & 0 & \\
\hline
\end{tabular}

localization of claudin-7 decreased at the membrane and exhibited diffuse staining at the cytoplasm (Fig. 3). One of the reasons to explain the differential expression of claudin-3 and claudin-7 exhibited by these two cell lines may be their functional differences. Caco-2 cells were isolated from a primary colonic tumor, while SW620 cells were established from the lymph nodes of a patient with colorectal adenocarcinoma $(52,53)$. Furthermore, SW620 cells are known to exhibit highly tumorigenic and metastatic features (54). Additionally, previous studies demonstrated that upregulation of claudin-3 was associated with increased tumorigenic potential in ovarian epithelial cells $(55,56)$, and that loss of claudin-7 was associated with increased cellular discohesion in breast carcinoma (30). Therefore, high expression of claudin-3 and low expression of claudin-7 in the metastatic colon cancer SW620 cell line may be associated with tumor cell proliferation and metastasis.

Several studies reported that patients with colorectal mucinous adenocarcinoma had a poorer prognosis compared with that of patients with non-mucinous adenocarcinoma (57-59). Differences in metastatic patterns between histological subtypes of colorectal cancer and a high number of peritoneal metastases in colorectal mucinous adenocarcinomas have also been reported (60-63). However, the underlying mechanisms for the differences in metastatic patterns between various histological subtypes remain unclear. Molecular and biological differences may be associated with the histological features and behaviors of different subtypes of colorectal cancer, and thus, the nuclear localization of claudin-3 may contribute to a more aggressive behavior. The present results indicated that 
claudin-3 serves a role in histological transformation, since the nuclear expression rate of claudin-3 was significantly increased in colorectal mucinous adenocarcinomas $(52.6 \%$, 10/19) compared with that in well- to moderately-differentiated colorectal adenocarcinomas $(14.8 \%, 12 / 81)$ (Table IV), and was also significantly increased $(\mathrm{P}=0.029$; data not shown) in advanced stage T4 $(35.5 \%, 11 / 31)$ compared with that in stages Tis-T3 $(15.9 \%, 11 / 69)$ (Table IV). Thus, additional studies are required in order to establish whether claudin-3 contributes to the regulation of tumor cell proliferation and metastasis in colorectal adenocarcinomas.

The nuclear localization of claudin-3 in colorectal adenocarcinoma cells is involved in the biological transformation of tumor behavior. The present results indicated that claudin-3 serves an important role in determining the tumor histological type and has potential as a prognostic marker. Although the mechanisms underlying the translocation of claudin-3 to the nucleus in tumorigenesis have not yet been elucidated in detail, the present study indicated the potential of claudin-3 as a histopathological biomarker for colorectal adenocarcinomas.

\section{Acknowledgements}

The present study was supported by the Japan Society for the Promotion of Science KAKENHI (grant no. JP15K08381).

\section{References}

1. Jemal A, Bray F, Center MM, Ferlay J, Ward E and Forman D: Global cancer statistics. CA Cancer J Clin 61: 69-90, 2011.

2. Weitz J, Koch M, Debus J, Höhler T, Galle PR and Büchler MW: Colorectal cancer. Lancet 365: 153-165, 2005.

3. Fearon ER and Vogelstein B: A genetic model for colorectal tumorigenesis. Cell 61: 759-767, 1990.

4. Huber MA, Kraut N and Beug H: Molecular requirements for epithelial-mesenchymal transition during tumor progression. Curr Opin Cell Biol 17: 548-558, 2005.

5. Thiery JP: Epithelial-mesenchymal transitions in development and pathologies. Curr Opin Cell Biol 15: 740-746, 2003.

6. Laskowski P, Klim B, Ostrowski K, Szkudlarek M, LitwiejkoPietryńczak E, Kitlas K, Nienartowicz S and Dzięcioł J: Local inflammatory response in colorectal cancer. Pol J Pathol 67: 163-171, 2016.

7. Matter K and Balda MS: Signalling to and from tight junctions. Nat Rev Mol Cell Biol 4: 225-236, 2003.

8. Tsukita S, Furuse M and Itoh M: Multifunctional strands in tight junctions. Nat Rev Mol Cell Biol 2: 285-293, 2001.

9. Mitic LL, Van Itallie CM and Anderson JM: Molecular physiology and pathophysiology of tight junctions I. Tight junction structure and function: Lessons from mutant animals and proteins. Am J Physiol Gastrointest Liver Physiol 279: G250-G254, 2000.

10. Mitic LL and Anderson JM: Molecular architecture of tight junctions. Annu Rev Physiol 60: 121-142, 1998.

11. Langbein L, Pape UF, Grund C, Kuhn C, Praetzel S, Moll I, Moll R and Franke WW: Tight junction-related structures in the absence of a lumen: Occludin, claudins and tight junction plaque proteins in densely packed cell formations of stratified epithelia and squamous cell carcinomas. Eur J Cell Biol 82: 385-400, 2003.

12. Itoh $\mathrm{M}$ and Bissell $\mathrm{MJ}$ : The organization of tight junctions in epithelia: Implications for mammary gland biology and breast tumorigenesis. J Mammary Gland Biol Neoplasia 8: 449-462, 2003.

13. Martin TA and Jiang WG: Tight junctions and their role in cancer metastasis. Histol Histopathol 16: 1183-1195, 2001.

14. Martin TA and Jiang WG: Loss of tight junction barrier function and its role in cancer metastasis. Biochim Biophys Acta 1788: 872-891, 2009.

15. Morita K, Furuse M, Fujimoto K and Tsukita S: Claudin multigene family encoding four-transmembrane domain protein components of tight junction strands. Proc Natl Acad Sci USA 96: 511-516, 1999.
16. McCarthy KM, Skare IB, Stankewich MC, Furuse M, Tsukita S, Rogers RA, Lynch RD and Schneeberger EE: Occludin is a functional component of the tight junction. J Cell Sci 109: 2287-2298, 1996.

17. Matter K, Aijaz S, Tsapara A and Balda MS: Mammalian tight junctions in the regulation of epithelial differentiation and proliferation. Curr Opin Cell Biol 17: 453-458, 2005.

18. Tsukita S, Yamazaki Y, Katsuno T, Tamura A and Tsukita S: Tight junction-based epithelial microenvironment and cell proliferation. Oncogene 27: 6930-6938, 2008.

19. Dhawan P, Singh AB, Deane NG, No Y, Shiou SR, Schmidt C, Neff J, Washington MK and Beauchamp RD: Claudin-1 regulates cellular transformation and metastatic behavior in colon cancer. J Clin Invest 115: 1765-1776, 2005.

20. Itoh M, Furuse M, Morita K, Kubota K, Saitou M and Tsukita S: Direct binding of three tight junction-associated MAGUKs, $\mathrm{ZO}-1, \mathrm{ZO}-2$ and ZO-3, with the $\mathrm{COOH}$ termini of claudins. J Cell Biol 147: 1351-1363, 1999.

21. Mineta K, Yamamoto Y, Yamazaki Y, Tanaka H, Tada Y, Saito K, Tamura A, Igarashi M, Endo T, Takeuchi K and Tsukita S: Predicted expansion of the claudin multigene family. FEBS Lett 585: 606-612, 2011.

22. Turksen K and Troy TC: Barriers built on claudins. J Cell Sci 117: 2435-2447, 2004

23. Swisshelm K, Macek R and Kubbies M: Role of claudins in tumorigenesis. Adv Drug Deliv Rev 57: 919-928, 2005.

24. Morin PJ: Claudin proteins in human cancer: Promising new targets for diagnosis and therapy. Cancer Res 65: 9603-9606, 2005.

25. Soini Y, Tommola S, Helin H and Martikainen P: Claudins 1, 3, 4 and 5 in gastric carcinoma, loss of claudin expression associates with the diffuse subtype. Virchows Arch 448: 52-58, 2006.

26. Miwa N, Furuse M, Tsukita S, Niikawa N, Nakamura Y and Furukawa Y: Involvement of claudin-1 in the beta-catenin/Tcf signaling pathway and its frequent upregulation in human colorectal cancers. Oncol Res 12: 469-476, 2001.

27. Leotlela PD, Wade MS, Duray PH, Rhode MJ, Brown HF, Rosenthal DT, Dissanayake SK, Earley R, Indig FE, Nickoloff BJ, et al: Claudin-1 overexpression in melanoma is regulated by PKC and contributes to melanoma cell motility. Oncogene 26: 3846-3856, 2007.

28. Lee JW, Hsiao WT, Chen HY, Hsu LP, Chen PR, Lin MD, Chiu SJ, Shih WL and Hsu YC: Upregulated claudin-1 expression confers resistance to cell death of nasopharyngeal carcinoma cells. Int J Cancer 126: 1353-1366, 2010.

29. Ikari A, Sato T, Watanabe R, Yamazaki Y and Sugatani J: Increase in claudin-2 expression by an EGFR/MEK/ERK/c-Fos pathway in lung adenocarcinoma A549 cells. Biochim Biophys Acta 1823: 1110-1118, 2012.

30. Kominsky SL, Argani P, Korz D, Evron E, Raman V, Garrett E, Rein A, Sauter G, Kallioniemi OP and Sukumar S: Loss of the tight junction protein claudin-7 correlates with histological grade in both ductal carcinoma in situ and invasive ductal carcinoma of the breast. Oncogene 22: 2021-2033, 2003.

31. de Oliveira SS, de Oliveira IM, De Souza W and Morgado-Diaz JA: Claudins upregulation in human colorectal cancer. FEBS Lett 579: 6179-6185, 2005.

32. Kinugasa T, Huo Q,Higashi D, Shibaguchi H, Kuroki M, Tanaka T, Futami K, Yamashita Y, Hachimine K, Maekawa S, et al: Selective up-regulation of claudin-1 and claudin-2 in colorectal cancer. Anticancer Res 27: 3729-3734, 2007.

33. Gröne J, Weber B, Staub E, Heinze M, Klaman I, Pilarsky C, Hermann K, Castanos-Velez E, Röpcke S, Mann B, et al: Differential expression of genes encoding tight junction proteins in colorectal cancer: Frequent dysregulation of claudin-1, -8 and -12. Int J Colorectal Dis 22: 651-659, 2007.

34. Ikari A, Watanabe R, Sato T, Taga S, Shimobaba S, Yamaguchi M, Yamazaki Y,Endo S, Matsunaga T and Sugatani J: Nuclear distribution of claudin-2 increases cell proliferation in human lung adenocarcinoma cells. Biochim Biophys Acta 1843: 2079-2088, 2014.

35. Livak KJ and Schmittgen TD: Analysis of relative gene expression data using real-time quantitative PCR and the 2(-Delta Delta C(T)) method. Methods 25: 402-408, 2001.

36. Schneider CA, Rasband WS and Eliceiri KW: NIH Image to ImageJ: 25 years of image analysis. Nat Methods 9: 671-675, 2012.

37. Japanese Society for Cancer of the Colon and Rectum: Japanese Classification of Colorectal Carcinoma. 8th edition, Kanehara, Tokyo, 2013. 
38. Jung H, Jun KH, Jung JH, Chin HM and Park WB: The expression of claudin-1, claudin-2, claudin-3, and claudin-4 in gastric cancer tissue. J Surg Res 167: e185-e191, 2011.

39. Zwanziger D, Badziong J, Ting S, Moeller LC, Schmid KW, Siebolts U, Wickenhauser C, Dralle H and Fuehrer D: The impact of CLAUDIN-1 on follicular thyroid carcinoma aggressiveness. Endocr Relat Cancer 22: 819-830, 2015.

40. French AD, Fiori JL, Camilli TC, Leotlela PD, O'Connell MP, Frank BP, Subaran S, Indig FE, Taub DD and Weeraratna AT: PKC and PKA phosphorylation affect the subcellular localization of claudin-1 in melanoma cells. Int J Med Sci 6: 93-101, 2009.

41. Rabinsky EF, Joshi BP, Pant A, Zhou J, Duan X, Smith A, Kuick R, Fan S, Nusrat A, Owens SR, et al: Overexpressed claudin-1 can be visualized endoscopically in colonic adenomas in vivo. Cell Mol Gastroenterol Hepatol 2: 222-237, 2016.

42. Islas S, Vega J, Ponce L and Gonzalez-Mariscal L: Nuclear localization of the tight junction protein ZO-2 in epithelial cells. Exp Cell Res 274: 138-148, 2002.

43. Gottardi CJ, Arpin M, Fanning AS and Louvard D: The junction-associated protein, zonula occludens-1, localizes to the nucleus before the maturation and during the remodeling of cell-cell contacts. Proc Natl Acad Sci USA 93: 10779-10784, 1996.

44. Kosugi S, Hasebe M, Tomita M and Yanagawa H: Systematic identification of cell cycle-dependent yeast nucleocytoplasmic shuttling proteins by prediction of composite motifs. Proc Natl Acad Sci USA 106: 10171-10176, 2009.

45. Du G, Gu Y, Hao C, Yuan Z, He J, Jiang WG and Cheng S: The cellular distribution of $\mathrm{Na}^{+} / \mathrm{H}^{+}$exchanger regulatory factor 1 is determined by the PDZ-I domain and regulates the malignant progression of breast cancer. Oncotarget 7: 29440-29453, 2016.

46. Kausalya PJ, Phua DC and Hunziker W: Association of ARVCF with zonula occludens (ZO)-1 and ZO-2: binding to PDZ-domain proteins and cell-cell adhesion regulate plasma membrane and nuclear localization of ARVCF. Mol Biol Cell 15: 5503-5515, 2004.

47. Fabbro M and Henderson BR: Regulation of tumor suppressors by nuclear-cytoplasmic shuttling. Exp Cell Res 282: 59-69, 2003.

48. Fagotto F, Glück U and Gumbiner BM: Nuclear localization signal-independent and importin/karyopherin-independent nuclear import of beta-catenin. Curr Biol 8: 181-190, 1998.

49. Kemler R: From cadherins to catenins: Cytoplasmic protein interactions and regulation of cell adhesion. Trends Genet 9 : 317-321, 1993.

50. Munemitsu S, Albert I, Souza B, Rubinfeld B and Polakis P: Regulation of intracellular beta-catenin levels by the adenomatous polyposis coli (APC) tumor-suppressor protein. Proc Natl Acad Sci USA 92: 3046-3050, 1995.
51. Liebner S, Corada M, Bangsow T, Babbage J, Taddei A, Czupalla CJ, Reis M, Felici A, Wolburg H, Fruttiger M, et al: Wnt/beta-catenin signaling controls development of the blood-brain barrier. J Cell Biol 183: 409-417, 2008.

52. Fogh J, Wright WC and Loveless JD: Absence of HeLa cell contamination in 169 cell lines derived from human tumors. J Natl Cancer Inst 58: 209-214, 1977.

53. Leibovitz A, Stinson JC, McCombs WB III, McCoy CE Mazur KC and Mabry ND: Classification of human colorectal adenocarcinoma cell lines. Cancer Res 36: 4562-4569, 1976.

54. Hewitt RE, McMarlin A, Kleiner D, Wersto R, Martin P, Tsokos M, Stamp GW and Stetler-Stevenson WG: Validation of a model of colon cancer progression. J Pathol 192: 446-454, 2000.

55. Agarwal R, D'Souza T and Morin PJ: Claudin-3 and claudin-4 expression in ovarian epithelial cells enhances invasion and is associated with increased matrix metalloproteinase-2 activity. Cancer Res 65: 7378-7385, 2005.

56. Kwon MJ, Kim SS, Choi YL, Jung HS, Balch C, Kim SH, Song YS Marquez VE, Nephew KP and Shin YK: Derepression of CLDN3 and CLDN4 during ovarian tumorigenesis is associated with loss of repressive histone modifications. Carcinogenesis 31: 974-983, 2010.

57. Symonds DA and Vickery AL: Mucinous carcinoma of the colon and rectum. Cancer 37: 1891-1900, 1976.

58. Umpleby HC, Ranson DL and Williamson RC: Peculiarities of mucinous colorectal carcinoma. Br J Surg 72: 715-718, 1985.

59. Minsky BD, Mies C, Rich TA, Recht A and Chaffey JT: Colloid carcinoma of the colon and rectum. Cancer 60: 3103-3112, 1987.

60. Hugen N, van de Velde CJ, de Wilt JH and Nagtegaal ID: Metastatic pattern in colorectal cancer is strongly influenced by histological subtype. Ann Oncol 25: 651-657, 2014.

61. Catalano V, Loupakis F, Graziano F, Torresi U, Bisonni R, Mari D, Fornaro L, Baldelli AM, Giordani P, Rossi D, et al: Mucinous histology predicts for poor response rate and overall survival of patients with colorectal cancer and treated with first-line oxaliplatin- and/or irinotecan-based chemotherapy. $\mathrm{Br}$ J Cancer 100: 881-887, 2009.

62. Chen JS, Hsieh PS, Hung SY, Tang R, Tsai WS, Changchien CR, Lin PY, Wang JY and Yeh CY: Clinical significance of signet ring cell rectal carcinoma. Int J Colorectal Dis 19: 102-107, 2004.

63. Mekenkamp LJ, Heesterbeek KJ, Koopman M, Tol J, Teerenstra S, Venderbosch S, Punt CJ and Nagtegaal ID: Mucinous adenocarcinomas: Poor prognosis in metastatic colorectal cancer. Eur J Cancer 48: 501-509, 2012. 